\title{
CORRESPONDENCE
}

\author{
Priorities in the NHS \\ E Ll Lloyd, fFARCS...........470 \\ Antipyrine half-life and clearance in \\ clinical practice \\ B Whiting, MD, and others..........471 \\ Sociological factors and female Olympic \\ potential \\ T Khosla, PHD. \\ Anti-inflammatory drugs for \\ rheumatoid arthritis \\ A K Clarke, MRCP, and others; E C \\ Huskisson, MD, and others........472 \\ Confidence limits \\ A W F Edwards, SCD. \\ Accidental injection of Immobilon \\ G N Volans, MD, and B A Whittle, PHD . . .472 \\ Enterotoxinogenic bacteria in Africa \\ B D Schoub, $M B$, and others... \\ Raised alpha-fetoprotein levels and \\ congenital defect \\ $N C$ Nevin, MD, and others. \\ Dosage of neomycin sulphate \\ G R Brown, BPHARM. \\ Early gastric cancer \\ O A N Husain, FRCPATH, and J M Grainger,

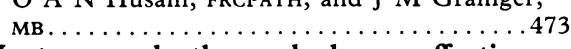 \\ Heat wave deaths and drugs affecting \\ temperature regulation \\ Surgeon Captain F P Ellis, FRCP. . . . . . . . 474 \\ Thyrotoxic vomiting \\ A J Isaacs, MRCP, and R D G Leslie, \\ MRCP; C E C Wells, FRCP... \\ Additives to intravenous fluids \\ B T Marsh, MB; P J Horsey, FFARCs ... . . .475
}

Anginal pain in a phantom $\operatorname{limb}$

Lord Cohen of Birkenhead, CH, FRCP . . . .475

Toxicity of paracetamol in children

P Crome, MRCP, and others...........475

Suicide with tricyclic antidepressants

M G Revill, MRCPSYCH.............. 475

The geriatric ward and the patient

N K Chakravorty, MRCPED; G P Oxborrow,

MB . . . . . . . . . . . . . . . . . . . . . . 475

New look at malaria

A F Tuboku-Metzger, fRCPGlas . . . . . 476

Alcoholism: wet hostels

A H de C Freed, MRCPSYCH. . . . . . . 476

Sedatives for alcoholics

A R Foster, MRCPSYCH............476

Seizures and metolazone

G H Gunson, MD ..............476

Abortion and maternal deaths

C B Goodhart, PHD .............477

Febrile fits

N S Gordon, fRCP............. . 477

BCG in cancer

$\mathrm{H}$ B Hewitt, $M D$, and $\mathrm{H}$ A $\mathrm{S}$ van den

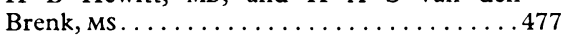

Raynaud's disease and the oral

contraceptive pill

H H Eastcott, FrCs . . . . . . . . . . 477

Economy in prescribing

D J Holdstock, MD . . . . . . . . . . 477

Dangers of tinted glasses for driving

C E Connolly, mrcpath............478
Elderly mentally ill

G Blessed, FRCPSYCH. . . . . . . . . 478

Reducing outpatient attendances

J K Morgan, FRCP. . ............. 478

Neuropathy in experimental diabetes

P K Thomas, FRCP, and A K Sharma, MB . .478

Requests for references

R S Atkinson, FFarcs, and others.....478

Bureaucratic cancer

J McE Potter, FRCs . ..............479

Private practice and the NHS

D P Choyce, frCs.............479

Unfair anomaly

A D Noble, FrCSED . . . . . . . . . . . . . . 479

BMA and HCSA

R B Martin. .

An academic backwater

D Jefferiss, FRCOG, and others. . . . . . . 480

Bank holidays and the NHS

A J P Willis, MRCP. . . . . . . . . . . . . 480

Waste in the NHS

S K Pathak, мB...............480

Legal action

A R Gaymer, MB; T S Wilson, MRCPATH;

Nancy $M$ Tweedie-Stodart, MB . . . . . . . . . 480

Juniors' contract dispute

D F H Guèret Wardle, MRCP. . . . . . . . . 480

Points from letters Action by consultants

(J A Findlay); Effects of legal termination on subsequent pregnancy (A George); Management of acute myocardial infarction (J F Pantridge;

J Kay).....................48
Correspondents are urged to write briefly so that readers may be offered as wide a selection of letters as possible. So many are being received that the omission of some is inevitable. Letters should be signed personally by all their authors.

\section{Priorities in the NHS}

SIR,-There is a great deal of discussion about priorities in the Health Service, with most people agreeing, at first, about the value of prevention and caring for the total needs of patients. However, as soon as details are discussed there is an outcry against any diminution of acute care facilities.

Dr I J T Davies (12 June, p 1449) attacks the idea that new lavatories for a geriatric block may get priority over an operating theatre for a burns unit and Mr A P J Ross (p 1450) says that no improvement in geriatric facilities will remove an old lady with intestinal obstruction from one of his surgical beds. Effective health education could reduce the number of road accidents or burns, thus relieving pressure on surgical beds and possibly obviating the need for the new theatre for the burns unit. This in turn would release money for new lavatories for the geriatric block and therefore, by allowing the geriatricians to provide a better service, could lead to an early postoperative transfer of $\mathrm{Mr}$ Ross's old lady for rehabilitation followed by a more rapid return home.

Despite recent evidence that orthopaedic surgeons $^{1}$ and anaesthetists ${ }^{2}$ are recognising special needs in the elderly, Dr J C Leonard (29 May, p 1335) admits to no clinical presentation of illness unique to geriatrics and feels that general physicians should have control over acute and long-stay beds. This misses the point. Many geriatricians view admission to hospital as failure of the aim to keep people healthy and at home, an aim that is now being suggested as the desired goal for all ages ( $\mathrm{Dr}$ A J Smith, 12 June, p 1449). It could be suggested that other specialties should follow geriatrics and combine preventive measures with therapy and rehabilitation and temper all with consideration of the total environment (social, economic, and psychological) of the individual patient. Incidentally, if failure to attract sufficient staff is a reason to consider scrapping a specialty, as suggested by $\mathrm{Dr}$ Leonard, anaesthetics and radiology stand beside geriatrics.

It takes time to educate any group of people, and Western man has an immense capacity for personal inertia and a tendency to over-react to any hint of interference with personal liberties, though exercise of these freedoms may inter- fere with the freedom of others. Two examples of this are: (1) Legislation on driving after drinking and on speed limits is greeted with howls of rage, but what about the interference caused by the drunk or speeding driver with the freedom of an innocent pedestrian knocked down and crippled? (2) A person who exercises his freedom to smoke (Dr L Sander, 12 June, p 1453) and develops lung cancer is regarded as a top priority for surgical admission and, by tying up beds and surgical expertise, may interfere with the freedom of choice of a person on a long waiting list who is unable to work due to a hernia.

Surely our top priorities must include: (1) reduction of extravagance whether administrative or, as suggested by Dr Anne Savage (10 July, p 114), in prescriptions and paramarmaladosis; (2) health education, not only about the individual's right to health care but also about the responsibilities he has for looking after his own health and avoiding damage to the health of others; and (3) care for the needs of all, especially those without political muscle, including the mentally (Dr J C Gunn, 3 July, p 41) and physically handicapped of all ages.

E LL LLOYD

Department of Anaesthetics Royal Infirmary, Edinburgh

' Devas, M, Annals of the Royal College of Surgeons of England, 1976, 58, 17 . England, 1976, 58, 21 . 